\title{
Sampling Guidelines and Recommendations for Submitting Samples for Diagnosing Laurel Wilt in Avocado Trees (Persea americana L.) ${ }^{1}$
}

\author{
Jonathan Crane, Romina Gazis, Jeff Wasielewski, Daniel Carrillo, Bruce Schaffer, Fredy Ballen, \\ and Edward Evans ${ }^{2}$
}

Laurel wilt (LW) is a vascular disease caused by a fungal pathogen, Raffaelea lauricola, which is transmitted to avocado trees by several ambrosia beetle species (e.g., Xyleborus bispinatus and $X$. volvulus) or through root grafts among adjacent avocado trees. Laurel wilt is a highly destructive disease that ultimately results in tree death; therefore, early detection and tree removal to prevent its spread is recommended. Diseased or symptomatic trees are best identified by continuous and regular grove scouting, which should be a normal grove management activity. This may go a long way to manage the disease and remain in business. For more information on laurel wilt and its vectors, please see the EDIS articles at https://edis.ifas.ufl. edu/hs1358 and https://edis.ifas.ufl.edu/hs1360.

A critical first step to prevent and/or control a plant disease is to identify the causal agent in order that appropriate management practices can be implemented to contain the outbreak. Proper sampling is a critical step in disease diagnosis to determine the causal agent of disease. Currently, sample collection for LW diagnosis requires collecting chips or slivers of sapwood (xylem) of wood from symptomatic avocado trees.
Typical external symptoms of LW-affected trees include leaf wilting, leaf browning (desiccation), and stem and limb dieback (Figure 1). External signs include cylindrical strands or toothpick-like protrusions of white sawdust coming out of small holes (entrance or exit beetle-boring sites) in the trunks of primary and secondary limbs (Figure 2). Sapwood symptomatic for the fungal pathogen that causes laurel wilt is light to dark brown with streaks of black, brownish, or bluish-black color (Figures 3A and 3B). In contrast, healthy sapwood is cream to off-white in color (Figure 3C).

\section{Equipment to Sample Symptomatic Trees}

A hatchet, plastic ziplock bags, permanent marker, gloves, and disinfectant (Figure 4A) are needed to collect samples. Examples of disinfectants include (1) $25 \%$ chlorine bleach (3 parts water and 1 part bleach); (2) 25\% pine oil cleaner (3 parts water and 1 part pine oil); (3) 50\% rubbing alcohol (70\% isopropyl; equal parts alcohol and water); (4) 50\% denatured ethanol (equal parts alcohol and water); and (5) $5 \%$ quaternary ammonium salts. There are ammonium

1. This document is HS1394, one of a series of the Horticultural Sciences Department, UF/IFAS Extension. Original publication date November 2020. Visit the EDIS website at https://edis.ifas.ufl.edu for the currently supported version of this publication.

2. Jonathan Crane, professor, Horticultural Sciences Department, and tropical fruit crops Extension specialist; Romina Gazis, assistant professor, Plant Pathology Department; UF/IFAS Tropical Research and Education Center; Jeff Wasielewski, commercial tropical fruit crops agent, UF/IFAS Extension Miami-Dade County; Daniel Carrillo, assistant professor, Entomology and Nematology Department; Bruce Schaffer, professor, Horticultural Sciences Department; Fredy Ballen, economic analyst; and Edward Evans, professor, Food and Resource Economics Department, and center director; UF/IFAS Tropical REC; UF/IFAS Extension, Gainesville, FL 32611.

The Institute of Food and Agricultural Sciences (IFAS) is an Equal Opportunity Institution authorized to provide research, educational information and other services

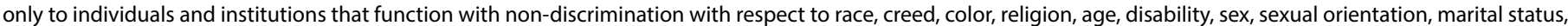

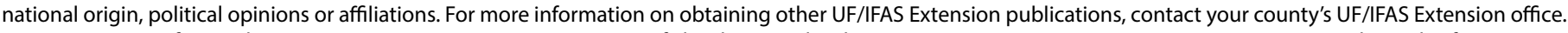
U.S. Department of Agriculture, UF/IFAS Extension Service, University of Florida, IFAS, Florida A \& M University Cooperative Extension Program, and Boards of County Commissioners Cooperating. Nick T. Place, dean for UF/IFAS Extension. 
chloride-based disinfectants (i.e., Green-Shield ${ }^{\circledast}$ or KleenGrow $^{\text {rix }}$ ) that are good disinfectants for cleaning tools. Do not mix quaternary ammonia products with bleach.
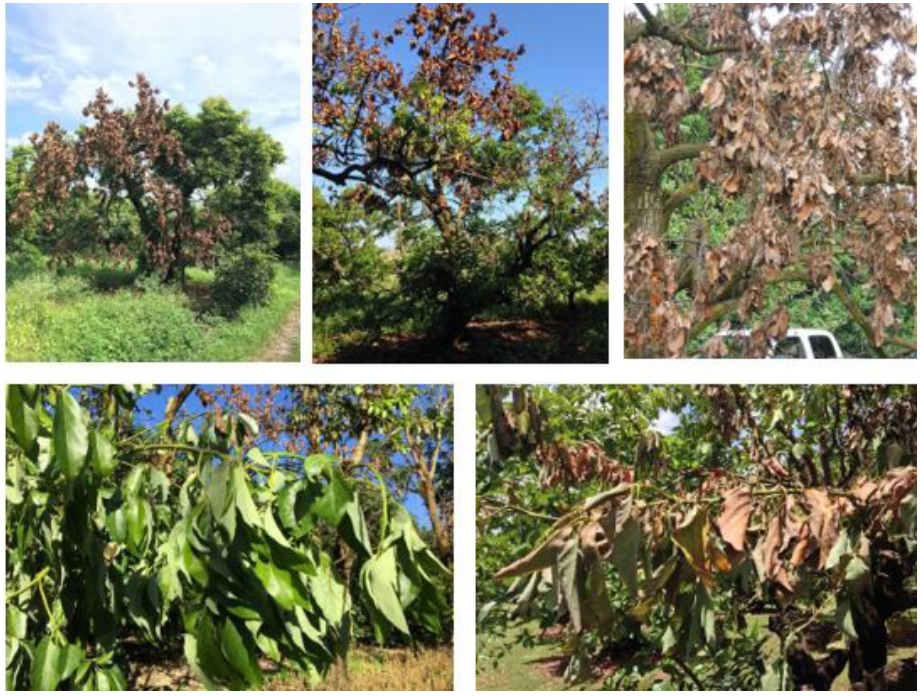

Figure 1. Laurel wilt symptoms in avocado trees include green leaf wilting, desiccated (brown) leaves, and stem and limb dieback. Credits: J. H. Crane, UF/IFAS TREC
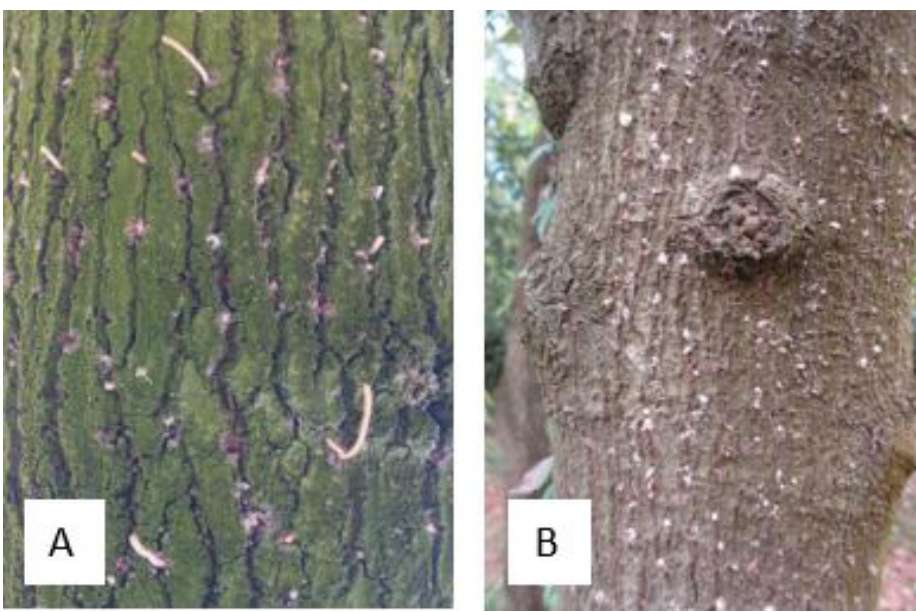

Figure 2. Signs of ambrosia beetle activity in avocado trees. Note the small circular sawdust mounds ( $A$ and $B$ ), sawdust tubes (A), straws and sawdust (B) from ambrosia beetle boring.

Credits: (A) J. H. Crane, UF/IFAS TREC and (B) D. Carrillo, UF/IFAS TREC

Information to write on the plastic or paper sampling bag (Figure 4B):

1. Cultivar (variety) of avocado

2. Collection date

3. Location of the tree (row, tree number, GPS coordinates)

4. Your name and contact information, including phone and email

\section{Where to Sample on the Tree}

Sample the areas of the tree showing signs of tree decline. First, look to see where the canopy is showing signs of decline (e.g., green wilting, desiccated leaves), then look for evidence of ambrosia beetle (e.g., sawdust mounds or tubes), and sample the limbs at or above these areas (Figure 2). If the whole tree is symptomatic, sampling the main trunk is okay. Take samples from two or more locations on a tree because the LW pathogen is not evenly distributed inside the tree and sampling multiple sites will increase chances of detecting the pathogen.

\section{Sampling}

Use the hatchet to cut through the bark. The bark of avocado trees can be thick ( $1 / 2$ to 1 inch or more) (Figures $4 \mathrm{~A}$ and $4 \mathrm{~B}$ ). The outer bark is rough and grayish colored, and the color of the inner bark is pink to pinkish orange. Remove the outer and inner bark until you reach the sapwood (the wood right below the bark). If this wood has dark (bluish-brown-black) streaks, this is an indication of the presence of the laurel wilt pathogen (Figures $3 \mathrm{~A}$ and $3 \mathrm{~B})$. If the sapwood is off-white (no dark streaks), this indicates the pathogen may not be present in that area (Figure 3C), so sample another area of the tree. Take chips of this symptomatic sapwood tissue and place them inside the collecting bag; about $1 / 2$ cup constitutes an adequate sample size (Figure 4B). Disinfect the hatchet after each tree to prevent the spread of the disease.
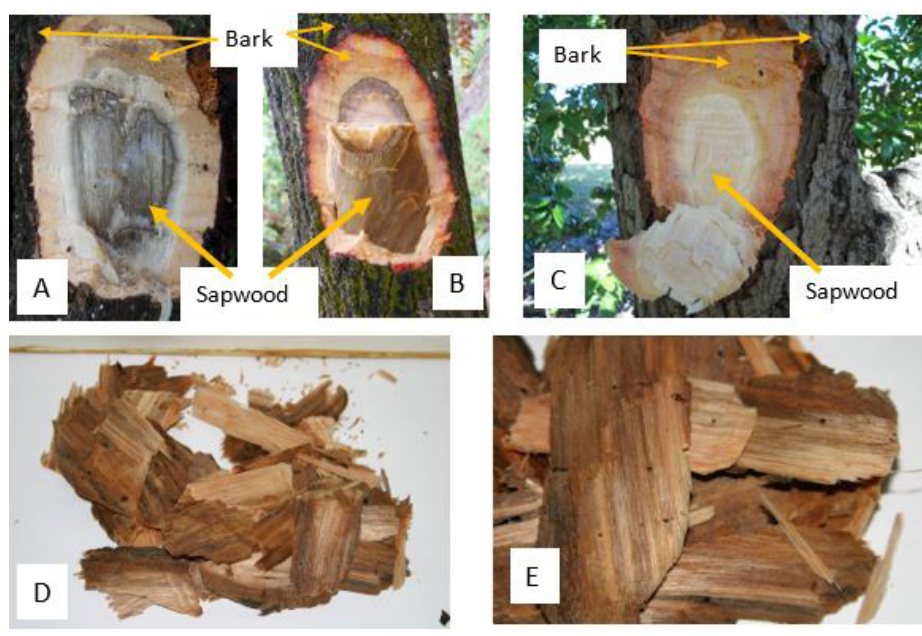

Figure 3. Sapwood of avocado trees showing internal symptoms of laurel wilt (A and B) vs. healthy sapwood (C), and wood chip samples including symptomatic vascular tissue ( $D$ and $E$ ).

Credits: J. H. Crane, UF/IFAS TREC 

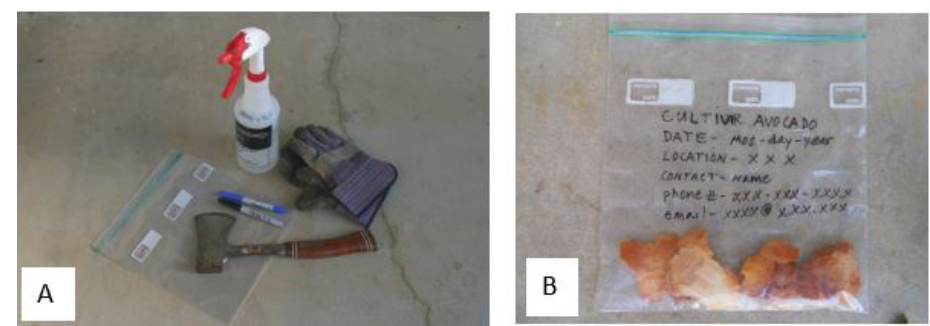

Figure 4. Hatchet, plastic ziplock bags, permanent marker, gloves, and disinfectant used for sampling avocado trees for laurel wilt diagnosis (A) and plastic bag with sapwood samples labeled with cultivar, date, location, and contact information (B).

Credits: J. H. Crane, UF/IFAS TREC

\section{Sample Diagnosis}

Take the labeled sample or samples to the UF/IFAS TREC Plant Diagnostic Clinic at 18905 S.W. 280 St., Homestead, FL 33031 (Figure 3B). Fill in the sample form sheet at the clinic; indicate it is for laurel wilt testing. The charge is $\$ 40.00$ per sample. Based on sample quality and workload already in the lab, the turnaround time should be within 3 days of sample delivery.

\section{Further Information and Instruction}

Please visit the UF/IFAS Solutions YouTube channel for a video demonstration of sampling for laurel wilt (https:// www.youtube.com/watch?v=OvjQWN8szGY\&t=8s) or contact the UF/IFAS TREC Plant Diagnostic Clinic: trec-pdc@ifas.ufl.edu or 786-217-9276.

\section{Acknowledgments}

This publication was supported in part by USDA-NIFA Grant (2015-51181-24257: Laurel wilt of avocado: Management of an unusual and lethal disease). 